\title{
When two academies meet
}

\author{
Peter Pockley in Sydney outlines attempts by \\ Australian science academies to encourage innovation
}

T WO learned academies in Australia are putting their weight behind a drive to educate the government and the public in the need for a higher level of local innovation in science and technology. The academies involved are the well-established Australian Academy of Science and the fledgling Australian Academy of Technological Sciences. Both have published booklets recently which catalogue and analyse the R\&D scene in Australia and which advocate, implicitly, increased government initiative in this area of industry*.

Australian industry is frequently attacked for lack of concern for local innovation and for preferring instead to import new ideas. The number of research staff employed in companies with R\&D capacity has dropped sharply, by an estimated $40 \%$ in the two years 1974-76. Sums invested in R\&D by industry itself, though harder to quantify, are believed to have decreased significantly. Dollars from the government for direct support of R\&D in industry, through an Industrial R\&D Grants scheme for example, have levelled off. And indirect government support, for example through a tax incentive scheme on industry's own investment in $\mathrm{R} \& \mathrm{D}$, has not been forthcoming.

Although the extent of overseas ownership of Australia industry has been a hot political issue in the $1970 \mathrm{~s}$, the accusation that companies controlled from overseas prefer to import their innovations is generalised largely from the vehicle industry; US-owned car companies reported no Australian innovations in 1970-75. UK- and USowned chemical industry, by contrast, shows a high rate of innovation within Australia. And some of Australia's more dramatic innovations of late have come from government-financed laboratories, notably in CSIRO, which have developed a successful collaboration with local industry. The present Committee of Inquiry into CSIRO is charged with recommending ways and means of facilitating further collaboration.

\section{Academy's Forum}

The Academy of Science recognised long ago the need for closer liaison with industrialists. Ten years ago it * From Stump-Jump Plough to Interscan (Austra-
lian Academy of Science, PO Box 216, Civic Square, Canberra, ACT 2608).

Sir Ian McLennan, Innovation in Australion Technology 1970-1975 (Australian Academy of Technological Sciences, Clunies Ross House, 191 Royal Parade, Parkville, Victoria 3052). established a Science and Industry Forum with equal membership of academicians (largely basic scientists but $\Sigma$ including a few with industrial experience) and representatives of industry (businessmen as well as technologists). A pretty informal group holding weekend discussions twice yearly, the Forum has eschewed making recommendations to government but has always managed to attract responsible Ministers and Heads of Departments to its meetings.

Its recently-published set of papers on innovation, under a catchy title and with a commercial distribution and sale system, reflects the Academy's more positive, public face. In the book Sir Alan Walsh, recently knighted for services to science, avers:

To my mind there are two obstacles to invention and innovation in Australia. The first has its roots in intellectual snobbery which results in many scientists believing that any type of scientific activity which has some real bearing on industry is intellectually and socially inferior to so-called pure research ... but probably the most serious obstacle is the widspread lack of faith in Australia's ability to generate inventions and innovations which can withstand competition from overseas. In view of Australia's record to date, this attitude is quite ridiculous

The Australian industrialist is more cautious. BHP, Australia's largest locally-owned company, has a good record in Australian-based research and development. Yet its chairman, Sir Ian McLennan, believes there needs to be a "very good reason to commit support to a local invention if the related aims can be satisfactorily met from an available overseas technical development which may be purchased. As there will always be a limit to funds available to develop local innovation these are better spent in a narrower range of likely successes than used over a wide range of relatively ineffectual help..."His comments illustrate a growing consciousness in Australia that it is time to formulate and pursue clear national policies on the encouragement of local innovation.

The Academy of Science is a going force in Australian science, and by far the strongest. With a permanent secretariat, though modestly sized by international standards, it is able to run a range of services to science which goes far wider than keeping happy the exclusive club of its Fellowship of 183 men and two women. The visible presence of its pleasing 'igloo' building

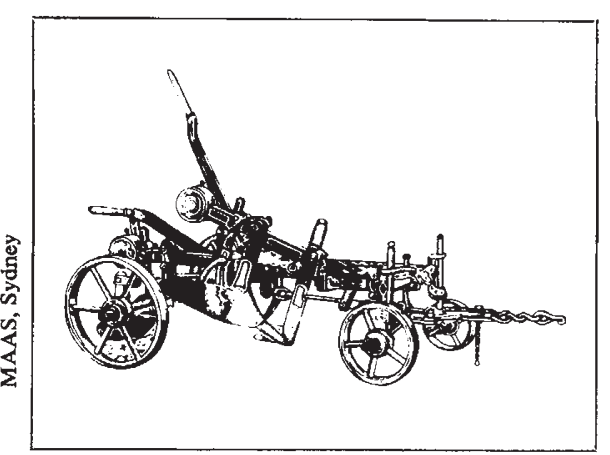

Australia's early innovation:

the stump-jump plough

on the boundary of the Australian National University has been a significant factor in its influence. Very much a national body, it locks naturally into the bureaucratic, political and academic ethos which dominates the totally nonindustrial capital of the nation.

This may have been one of the factors behind a mild blizzard around the Academy's igloo in the 1960s and early 1970s, when a gentle argument about recognition of the applied sciences built up a vortex of discontent. The storm blew around the igloo, only the mildest of breezes being felt within. One of the non-Academician activists was Dr W. A. S. Butement, a former Chief Defence Scientist. He had been leading a move by an informal group dissatisfied with the Academy's terms of admission to Fellowship; these emphasise, as the prime criterion, traditional academic achievement as perceived by peer group elections. The dissenting outsiders tried to persuade the Academy to broaden its terms to include "scientists, engineers and technologists of real worth, who are concerned with the application of science".

Constrained by the terms of its Royal charter, the Academy stuck to its chosen path. Shortly afterwards, however, it did admit to Fellowship some industrially employed scientists. As well as enjoying high standing in the hierarchy of industry, these were men with substantial publications to their name which satisfied the traditional criteria for election of basic scientists. The great majority of technologists employed in industry, universities and government departments were anonymous people by comparison. Thus began a concerted move, centred on an existing, loosely-structured forum of industrial research managers called the Australian Industrial Research Group, for a separate technological academy.

\section{Technological Academy}

The Australian Academy of Technological Sciences was formally inaugurated in February 1976 under the Presidency of Sir Ian McLennan. 
Symbolically, the function occurred in Melbourne, one of the nation's two large industrial and financial capitals; the foundation Fellowship was of 64 men and two women. The earlier rift with the Academy of Science was healed, and cooperation was ensured by the presence of 12 Fellows of the 8 Australian Academy of Science. Criteria for election to Fellowship of the new Academy emphasise innovation, but giving to the achievements of its Fellows a collective, collegiate character is a challenge the Academy has not yet solved.

The "suitable safeguards" surrounding government or industrial documents which involve public reticence on the part of its Fellows put the applied Academy at something of a disadvantage in the public prestige stakes when compared with the freer Academy of Science. The technologists have one potential advantage in coming largely from well-heeled industries which should need little persuading to fork out financial support. But a year-anda-half after inauguration, the new Academy is still walking along rather than jogging. In its first eight months of operation to mid-1976, it spent a mere $\$ 4,000$. It now maintains a parttime office in Melbourne, but is run on a spare-time basis by busy men. It badly needs to establish a permanent secretariat to service its present needs and future ambitions.

\section{AAS's igloo}

These ambitions are presently centred on the promation of innovation in industry and government, and on the mounting of a series of annual conferences on the general theme of "Energy and Resources to 2000". The first of these, scheduled for later this year, is on "Fuel and Energy Resources", followed by "Water and Land Resources" in 1978, "Mineral Resources" in 1979, and "Marine Resources" in 1980. And of course a start has been made in publishing the first results of a review of innovative technological achievement in Australia.

One hundred years ago this year, Australia's first industrially successful innovation was registered-the stumpjump plough. It opened up vast tracts of otherwise useless land to cultivation. This year sees a number of internationally competitive innovations beginning to get public recognition. Successful developments, such as the compact Self-Twist Spinning Machine, the Sirotherm process for desalination by thermally regenerated resins, and the Interscan system for aircraft landing control in three dimensions, may begin to persuade government and industry alike that the two Academies are speaking economic sense when they urge more active support for locally based R\&D.

\section{Making paper work}

\section{Christine Thomas explains the advantages in using recycled and mechanical pulp papers}

$\mathrm{F}^{\mathrm{m}}$ EW people are aware, when they purchase good quality writing paper in pneference to rougher note paper, or choose extra-soft toilet tissue rather than lower quality crepe tissue paper, that they are contributing to increasing environmental pollution. But investigation of the demand upon resources and the polluting effects of specific processes involved in paper production highlights the considerable differences in the environmental impact of different papers. The general picture that emerges is that the higher the quality of the paper produced, the greater the resource demand and pollution load created.

Paper consists of a network of fibrillated cellulose fibres bonded together by their gelatinous surfaces.

Christine Thomas, author of The Paper Chain, is a researcher at Earth Resources Research $L_{t d}$, London
The fibres are released from their plant structure during pulping, which for timber can be either by chemical or mechanical means. Chemical pulping methods use chemical solutions to dissolve away part of the plant structure, leaving the cellulose fibres whole and separated with minimum physical damage. Chemical pulp-based papers are considered for many purposes to be superior in quality to mechanical pulpbased papers. Mechanical pulps are generally weaker than chemical pulps and suffer from colour darkening.

Mechanical pulp papers, however, are of adequate quality for many uses, including newsprint, low grade printing papers, fibreboard, wrapping papers, and some tissues. And mechanical pulping provides a more efficient use of timber with a 90-95\% yield of pulp from cut, dried wood compared to $40-65 \%$ for chemical pulping. Put another way, where it takes on average 13 trees to produce a tonne of chemical pulp, only six would be needed for mechanical pulp. And it is not only the resource demands of chemical pulp which are greater. Its production also creates a significantly more polluting effluent, and consumes more water than does mechanical pulping (see Table 1).

Waste paper can be recycled by repulping and releasing the cellulose fibres from their existing network to allow them to be reformed into a new sheet. Naturally the substitution of recycled papers for those containing virgin pulp will result in a reduction in demand for wood pulp, and will lessen the problems of solid waste disposal. In addition, however, it will result in a reduction of energy demand, of the order of $50 \%$ of the energy required for the wood pulping process. It may also lead to less overall pollution, and a saving in water (see Table 2).

Recycled papers themselves vary considerably. Because the fibres have previously been prepared for papermaking, the recycling process in theory is simpler than pulping wood. In practice, though, there are complications introduced by the presence of ink and 